\title{
KRITIK RADIKALISME PEMIKIRAN HTI: \\ Studi Kontekstualitas Matan Hadis-Hadis Khiläfah
}

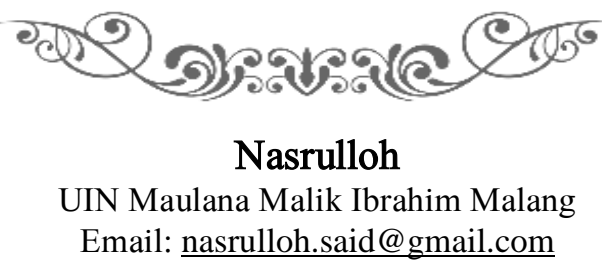

\begin{abstract}
This paper is an academic step to discover a scientific fact through the study of hadith texts that legitimize the ideological truth of the HTI group. In generating radical thoughts, the HTI group has a main reference, a book entitled Nizāam al-Hukm fì alIslām, written by the founder of Hizb al-Tahrir, Taqiyuddin alNabhani. In this study, the themes of the hadiths discussed are those related to the khilafah (caliphs) contained in the book and in the sub-chapter of Al-Khilafah (the Caliphate). The book was chosen because it is the main reference book of HTI that cites hadiths which are textually radical. Some key points that become the objectives of this study are: (1) What is the status of the authenticity of khilafah hadiths?, (2) How is the contextual understanding of khilafah hadiths?, and (3) What are the implications of HTI's understanding of khilafah hadiths in the context of the Unitary State of the Republic of Indonesia?
\end{abstract}

Keywords: Religious Radicalism, HTI, Hadiths of Khalifah.

\begin{abstract}
Abstrak
Tulisan ini merupakan langkah akademik untuk menemukan sebuah fakta ilmiah melalui kajian teks hadis yang dijadikan legitimasi bagi kebenaran ideologi kelompok HTI. Dalam melahirkan pemikiran-pemikiran yang radikal, kelompok HTI mempunyai referensi utama yaitu buku yang ditulis oleh pendiri Hizbut Tahrir, Taqiyuddin al-Nabhanì, yang berjudul Nizāam alHukm fî al-Islām. Dalam penelitian ini, tema-tema hadis yang diusung adalah hadis-hadis yang berhubungan dengan khiläfah yang terdapat dalam buku tersebut dan dalam sub bab alKhilafah. Buku tersebut dipilih karena buku itu merupakan rujukan utama HTI yang banyak menukil hadis-hadis yang secara tekstualis bernuansa radikal. Beberapa hal penting yang menjadi tujuan dalam tulisan ini adalah: (1) Bagaimana status
\end{abstract}


autentitas hadis-hadis khilafah?, (2) Bagaimana kontekstualitas pemahaman hadis-hadis khilafah?, dan (3) Bagaimana implikasi pemahaman HTI terhadap hadis-hadis khilafah dalam konteks NKRI?

Kata Kunci: Radikalisme Agama, HTI, Hadis-Hadis Khilafah.

\section{PENDAHULUAN}

Salah satu isu Nasional tahun ini adalah isu pembubaran ormas yang dianggap bertentangan dengan ideologi pancasila. Salah satu ormas yang ingin mengganti ideologi negara Pancasila dengan ideologi lain adalah Hizbut Tahrir Indonesia (HTI). Kelompok HTI bercita-cita mengganti ideologi Pancasila dengan ideologi Khiläfah. Tentunya hal ini berseberangan dengan UUD 1945. Oleh karena itu pemerintah pada tahun 2017 secara resmi membubarkan ormas tersebut. Dengan adanya pencabutan SK Badan Hukum HTI, maka ormas tersebut dinyatakan bubar sesuai dengan Perppu Nomor 2 Tahun 2017 Pasal 80A. ${ }^{1}$

HTI berkeinginan mengganti ideologi negara Pancasila dengan ideologi khiläfah bukan tanpa dasar. Mereka dalam beberapa argumentasi yang disampaikan bahwa ideologi negara yang berasaskan khiläfah sesuai dengan Alquran dan Hadis. Kehadiran mereka ditengah-tengah masyarakat Indonesia masih ada karena ideologi yang mereka usung selalu dibumbui dengan teks dari Alquran dan Hadis.

Dalam sebuah hadis sahih Muslim yang dikutip oleh pendiri Hizbut Tahrir yaitu Taqiyuddin al-Nabhany disebutkan bahwa Nabi Saw. bersabda: "Jika ada dua khalifah yang di baiat, maka bunuhlah salah satu dari mereka." 2 Tidak dipungkiri bahwa pemahaman yang parsial seperti dalam redaksi teks hadis tersebut bila dipahami tanpa melibatkan historisitas sebuah teks akan melahirkan pemahaman-pemahaman yang radikal. Pemahaman kelompok ini terhadap sebuah teks dapat dikategorikan tekstualis-parsialis seehingga wajar menghasilkan pemahaman yang radikal. ${ }^{3}$ Hadis tersebut menjelaskan bahwa jika ada dua khalifah yang dibaiat maka bunuhlah salah satunya. Hadis tersebut masih bersifat umum, wajar saja jika akan terjadi kekacauan jika ada dua pemimpin dengan derajat yang sama dalam sebuah negara, jika memang terjadi dua kepemimpinan dengan satu derajat yang sama, pastinya ada salah satu yang tidak sah, maka boleh dibunuh salah satunya, itupun sebagai alternatif paling terakhir bila tidak

1 http://nasional.kompas.com/read/2017/07/19/10180761/hti-resmi-dibubarkanpemerintah Diakses tgl 1-08-2017

${ }^{2}$ Muslim ibn Hajjaj al-NaysAbūrí, Sahịh Muslim. Tahqiq: Muhammad Abd alBaqy (Bayrūt: Dār Ihya al-Turats al-Araby, tt), jil 4, 1480.

3 Lihat; Umi Sumbulah, Konfigurasi Fundamentalisme Islam (Malang: UIN Malang Press, 2009). 
ditemukan solusi selain membunuhnya, demikian ini disampaikan oleh Imam al-Nawawi dalam Sharah Muslimnya. ${ }^{4}$ Bahkan Nabi Saw. sendiri dalam sebuah hadisnya menegaskan pentingnya pemimpin dalam berbagai kumpulan atau kelompok, seperti rombongan bepergian dianjurkan oleh Nabi untuk mengangkat pemimpin. ${ }^{5}$ Kesalahan pemikiran HTI adalah pemahamannya yang tekstual dan mengeneralisir seluruh dunia harus satu pemimpin, ${ }^{6}$ kenyataannya banyak dari sahabat yang menjadi khalifah atau pemimpin di negara-negara yang berbeda. Nabi Saw. tidak pernah dalam satupun hadisnya menyampaikan tentang sistem pemerintahan dalam sebuah Negara, hal ini dibuktikan dengan proses pemilihan empat Khulafa' alRāshidin berbeda-beda, ada yang menggunakan sistem musyawarah atau demokrasi seperti Abu Bakar r.a. ada juga yang dengan sistem tunjuk tanpa musyawarah seperti Umar r.a.

Kelompok HTI mempunyai ciri tekstualis yang menonjol dalam pemahamannya terhadap sebuah teks. Teks-teks tersebut menjadi legitimasi atas pemikiran dan tindakan mereka dalam berprilaku sehari-hari. Sedikit berbeda dengan catatan sebelumnya, maraknya pemikiran radikalisme dan trend pemerintahan yang dianggap kafir menurut Khalil 'Abd al-Karim karena dua sebab. Pertama, munculnya teori hăkimiyah yang digulirkan oleh Sayyid Qutub yang diadopsi dari Abū al-A'lā al-Mawdudi. Teori tersebut mengambil dari firman Allah Swt. dalam Alquran, bahwa siapa yang tidak menjadikan aturan Allah sebagai sandaran maka ia termasuk orang yang kafir, munafik dan fasiq. Kedua, gencarnya penindasan dan diskriminasi terhadap kaum radikalisme yang ditandai dengan dihukumnya Sayyid Qutub dengan hukuman gantung. ${ }^{7}$

Tulisan ini merupakan langkah akademik dan ilmiah untuk menemukan sebuah fakta melalui kajian teks hadis yang dijadikan legitimasi bagi kebenaran ideologi mereka.

Dalam melahirkan pemikiran-pemikiran yang radikal, kelompok HTI mempunyai referensi utama yaitu buku yang ditulis oleh pendiri Hizbut Tahrir yaitu buku yang berjudul Nizām al-Hukm fí al-Islām yang ditulis oleh Taqiyuddin al-Nabhany. Dalam kajian ini, tema-tema hadis yang diusung adalah hadis-hadis yang berhubungan dengan khiläfah yang terdapat dalam buku tersebut dan dalam sub bab al-Khilăfah. Buku tersebut dipilih karena

4 Muhyiddin Yahya ibn Sharaf al-Nawawi, al-Minhaj Syarah Sahịh Muslim (Bayrūt: Dār Iḥya al-Turath, 1392H), Vol 12, 242.

5 Abū Dāwud Sulaymān al-Sajistānì, Sunan Abī Dāwud (Bayrūt: al-Maktabah al'Asriyyah, tt), vol 3, 36.

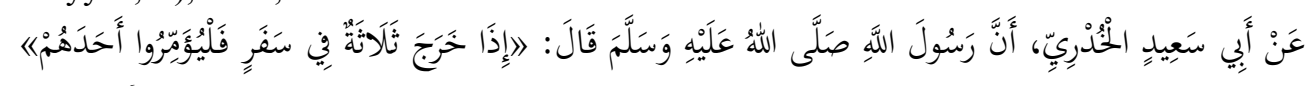

6 Taqiyuddin al-Nabhanī, Nizāam al-Hukm fí al-Islām (Manshurat Hizb al-Tahrir, 2002), 44 .

${ }^{7}$ http://jombang.nu.or.id/kritik-pemikiran-hiszbut-tahrir-2/ diakses tgl 22-05-2018

Vol 7, No. 02, Desember 2019 
memang itu adalah buku rujukan utama HTI yang banyak menukil hadishadis yang secara tekstualis bernuansa radikal.

Melihat latar belakang masalah yang telah dipaparkan di atas, maka beberapa hal penting yang menjadi tujuan dalam tulisan ini adalah: Bagaimana kontekstualitas pemahaman hadis-hadis khiläfah? Bagaimana implikasi pemahaman HTI terhadap hadis-hadis khiläfah dalam konteks NKRI? Dengan demikian, tujuan dari kajian ini yang dipandang penting adalah untuk mengetahui status autentitas hadis-hadis khiläfah, mengetahui kontekstualitas pemahaman hadis-hadis khiläfah, dan mengetahui implikasi pemahaman HTI terhadap hadis-hadis khiläfah dalam konteks NKRI.

Beberapa hasilkajian kajian atau karya ilmiah yang bersentuhan dengan khalifah dan khiläfah, di antaranya; pertama, yang dilakukan oleh 'Abd al-Rahịim dengan judul Khalifah Dan Khiläfah Menurut Alquran. ${ }^{8}$ Kajian ini merupakan kajian yang sederhana tentang khalifah dan khiläfah secara umum tanpa membatasi analis kata khiläfah dalam Alquran. Ia juga tidak menyebutkan metode yang digunakan, ia membahas tentang unsureunsur khilāfah, tugas-tugas khalifah, cara khalifah menyelesaikan masalah dll. Kajian tersebut cakupannya amat luas dan dalam perspektif Alquran.

Kedua, Kajian yang dilakukan oleh Rosy Selly yang berjudul Globalisasi dan Kebangkitan Khiläfah Islamiyah Dalam Perspektif Pemikiran Hizbut Tahrir. ${ }^{9}$ Kajian ini hanya terfokus pada pemikiran Hizbut Tahrir tentang khilăfah Islamiyah. Temuan dari kajian ini mengungkapkan bahwa pemerintahan dengan sistem khilāfah merupakan sebuah solusi dari sebuah keterpurukan global. Kelompok HTI memanfaatkan sains dan teknologi yang berkembang pesat di era globalisasi sebagai sarana mengembangkan ideologinya. Kajian yang dilakukan Rosy Selly ini tent unya tidak bersentuhan dengan kajian khiläfah ditinjau dari sisi hadis.

Ketiga, Konsepsi Khiläfah Dalam Alquran yang ditulis oleh Ida Fuaida. ${ }^{10}$ Kajian ini memiliki cakupan yang luas tidak hanya mencermati kata khalifah tapi juga semua kata yang memiliki kesamaan atau kedekatan makna seperti wali, sultān, uli al-amr, dan sebagainya. Kajian ini menemukan bahwa kata khiläfah dan derivasinya disebutkan dalam Alquran sebanyak 127 kali. Kajian ini juga menjelaskan bahwa asas musyawarah adalah asas kepemimpinan Qur'ani. Dilihat dari kesimpulan dari kajian tersebut, nampak jelas bahwa kajian tersebut tidak focus terhadap aspek kata khalifah, begitupun asas kepemimpinan dalam Alquran yang

${ }^{8}$ Abd Rahim, "Khalifah dan Khilafah Menurut al-Qur'an," Jurnal Hunafa: Jurnal Studi Islamika Vol. 9. No 1, (Juni 2012):

${ }^{9}$ Rosy Selly, Kebangkitan Khilafah Islamiyah Dalam Perspektif Pemikiran Hizbut Tahrir. (Jakarta: UIN Syarif Hidayatullah, 2008).

${ }^{10}$ Ida Fuaida, Konsepsi Khilafah Dalam Al-Qur'an (Surabaya: IAIN Sunan Ampel, 1997). 
menggunakan asas musyawarah merupakan temuan kajian yang dirasa masih global dan umum.

Keempat, Jurnal yang ditulis oleh Oksep Adhayanto dengan judul Khiläfah Dalam Sistem Pemerintahan Islam. Kajian tersebut tidak mengacu pada kajian Alquran sebagai dasar metode kajiannya. Hasil temuan kajian tersebut menyimpulkan bahwa bentuk Negara khiläfah adalah tunggal, berbeda dengan bentuk demokrasi. Sistem pemerintahan Islam mengacu pada syariat agama. Kajian ini terkesan umum dan tidak membatasi pada wilayah khiläfah yang lebih rinci, dilihat dari judul, metode dan hasil kajiannya, wilayah kajian amat luas dan penulisnya banyak mengambil buku-buku referensi yang mendukung tegaknya Negara khiläfah.

Empat judul kajian yang telah disebutkan, merupakan temuan hasil kajian yang dianggap masih punya kaitan dengan khiläfah. Dari beberapa kajian yang sudah ada, secara substantif dan wilayah kajiannya, masih belum dijumpai persamaan kajian ini dengan kajian-kajian sebelumnya.

Adapun jenis kajian ini adalah library research, yaitu teks hadishadis tentang khiläfah sebagai sumber primer datanya. Hadis-hadis tersebut akan dikaji dan ditelusuri dalam al-kutub al-tis'ah. Setelah itu masingmasing periwayat hadis dalam sanad tersebut akan diteliti tingkat ke-ḍābitannya melalui kitab-kitab taräjum al-tabaqāt. Tela'ah terhadap kitab-kitab penjelas hadis-hadis khiläfah dilakukan untuk mengetahui status hadis dilihat dari segi shädh dan 'illat-nya.

Pendekatan kritik hadis sanad dan matannya merupakan pendekatan yang digunakan dalam tulisan ini. Pendekatan ini dipilih menyesuaikan kajian yang memfokuskan pada teks hadis-hadis khiläfah. Standarisasi kesahịh-an sanad, dalam kajian mengikuti pada standar yang telah ditetapkan oleh Ibn Șalāh, yaitu sanad hadis dinyatakan otentik jika sanad-nya bersambung, rāwi-nya 'àdil, ḍābit, tidak adanya shādh dan 'illat. ${ }^{11}$ Adapun standar kritik matan yang diusung oleh al-Damini yang telah disebutkan pada sub bab kajian teori adalah standar kritik yang menjadi acuan kajian ini.

Sumber data yang digunakan dalam kajian ini meliputi sumber data primer, skunder dan tersier. Sumber data primer dalam kajian ini yaitu, Nizām al-Hukm fí al-Islām karya Taqiyyuddin al-Nabhany.

Dalam kajian ini penulis menelusuri berbagai rujukan yang berkaitan dengan hadis-hadis tentang khiläfah, di antaranya Sahịh Muslim, Saḥịh alBukharì, Sunan al-Tirmidhī, Sunan Abū Dāwud, Sunan al-Nasā'ì, Muwatta' Mālik, Musnad Aḥmad, Sunan Ibn Mājah, dan Musnad al-Darimì. Adapun data Skunder yang digunakan adalah Tuhfät al-Aḥwadhì karya alMubarakfuri, Sharh Sahịh Muslim Muslim karya Imam al-Nawawì, 'Awn alMa'bud Sharḥ Sunan Abū Dāwud karya Muhammad Abadi, Fatḥ al-Bārī

${ }^{11}$ Ibn Șalāh, Ma'rifăt Anw̄à'i 'Ulūm al-Ḥadith, 10. 
Sharh Sahịh al-Bukharī karya Ibnu Hajar al-'Asqalani, dan bebrapa buku yang berhubungan dengan pemaknaan hadis-hadis khiläfah. Selain bukubuku yang telah disebutkan, artikel, makalah dan jurnal serta beberapa referensi di media masa dijadikan referensi dalam kajian ini.

Sesuai dengan judul yang akan dikaji dalam kajian ini, analisis data yang digunakan adalah content analysis. Agar lebih jelas akan dipaparkan langkah-langkah analisis data yang akan ditempuh dalam kajian ini. Pertama; mengklasifikasi hadis-hadis khilāfah yang ada dalam buku Nizām al-Hukm fí al-Isläm. Kedua, melakukan I'tibar al-Hadith atau kajian sanad Ketiga, menerapkan kaidah ke-sahih -an matan. Keempat, melakukan kontekstualitas hadis-hadis khiläfah. Kelima, mengambil kesimpulan dengan pemahaman yang kontekstual sebagai dasar pemahaman makna hadis yang sesuai.

Roadmap dalam kajian ini berdasarkan topik yang dikaji, maka langkah-langkah yang akan ditempuh dalam kajian ini yaitu; pertama, kajian terhadap hadis-hadis khilāfah yang ada dalam kitab Nizăm al-Hukm fí alIsläm dalam al-kutub al-tis'ah secara comprehensive yang meliputi kajian Takhrij al-Hadith dan I'tibar al-Hadith atau biasa disebut sebagai kritik autentitas sanad dalam masing-masing hadis tersebut. Kedua, menelusuri asbāb wurüd hadith atau historisitas hadis-hadis permusuhan terhadap nonmuslim. Ketiga, meneliti makna hadis secara tekstual dan kontekstual dengan melibatkan historisitas munculnya hadis-hadis permusuhan terhadap non-muslim.

\section{PEMBAHASAN}

\section{Kajian dan Kerangka Teori}

Dalam bahasa Arab radikalisme disebut dengan al-tatarruf al-din $\bar{i}$ yang mempunyai makna berlebihan dalam melaksanakan Agama. Radikalisme masuk dalam kategori suatu aliran yang menginginkan adanya perubahan terhadap suatu kondisi atau aspek-aspek di masyarakat secara mendasar sampai ke akar-akarnya. ${ }^{12}$ Radikalisme juga bisa diartikan sebagai suatu carar pandang yang menghendaki perubahan terhadap status quo dengan jalan peleburan atau pengrusakan secara total, dan menggantinya dengan sesuatu yang baru atau sesuatu yang sama sekali berbeda, untuk mencapai tujuannya biasanaya ditempuh dengan kekerasan dan aksi-aksi ekstrem. ${ }^{13}$ Ketika agama sudah memasuki ranah ideologi, maka ia merupakan suatu konsep dan nilai yang harus diperjuangkan dan

\footnotetext{
2014), 116.

2. Zuli Qadir, Radikalisme Agama di Indonesia (Yogyakarta: Pustaka Pelajar,

13 Juergensmeyer Marx, Teror Atas Nama Tuhan : Kebangkitan Global kekerasan Agama (Jakarta: Nizam Press \& Anima Publishing, 2002). 5.
} 
dipertahankan dengan cara apapun, termasuk dengan cara kekerasan dan tindakan-tindakan anarkis yang justru berlawanan dengan nilai-nilai agama itu sendiri. Salah satu munculnya sikap radikalisme ini yaitu adanya religious commitment dari pemahaman agama yang salah. ${ }^{14}$ Kajian ini akan menelusuri dan menelaah secara mendalam tentang hadis-hadis yang biasa dijadikan alasan dan legitimasi atas tindakan dan aksi-aksi ekstrem mereka, akan tetapi hanya terfokus pada hadis-hadis khiläfah.

Hadis-hadis yang akan diteliti dalam kajian ini yaitu;

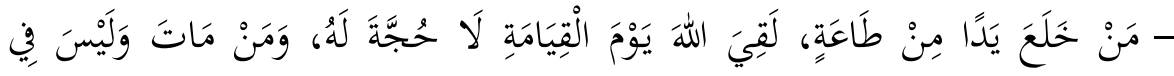

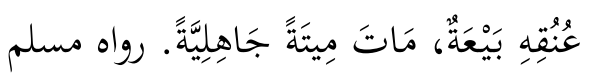

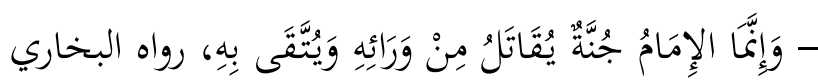

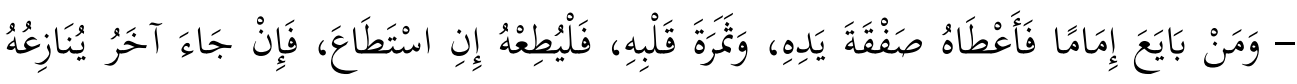

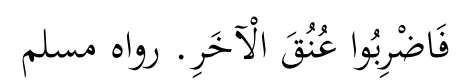

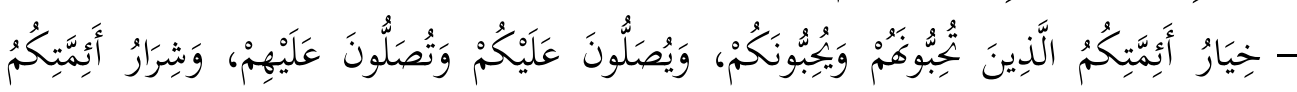

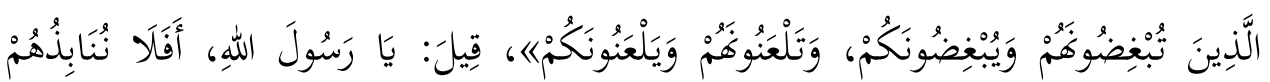

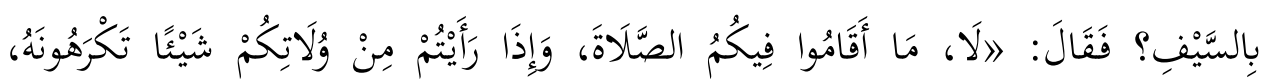

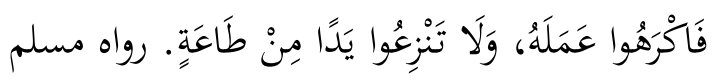

Autentitas sanad hadis-hadis khiläfah setidaknya harus memenuhi kriteria standar yang telah dijelaskan oleh Ibn Ṣalạ̄ sebagai berikut;

$$
\begin{aligned}
& \text { أما الحديث الصحيح فهو الحديث المسند الذي يتصل إسناده بنقل العدل الضابط عن }
\end{aligned}
$$

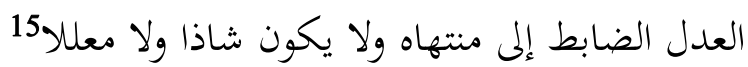

"Adapun hadis sahịh ialah hadis yang bersambung sanadnya, diriwayatkan oleh periwayat yang adil dan dâabit sampai akhir sanad, tidak terdapat kejanggalan dan cacat."

Definisi yang dikemukakan oleh Ibn Șalāh ini disetujui oleh banyak ulama hadis hingga saat ini, seperti Ibn Hạjar al-'Athqalāni (W $852 \mathrm{H}$ ), alSuyūtì (W 911 H), Jamāl al-Dīn al-Qāsimì (W 1332 H), Muḥammad Zakariya al-Kandahlawī (W 1315 H), Maḥmūd al-Ṭaḥ̣ān, Șubḥi Ș̣ālih (W 1407 H/ 1986 M), Muḥammad 'Ajāj Khātib. ${ }^{16}$ Ibn Kathīr (W 774 H/ 1373 M) mengakui bahwa mayoritas ulama hadis memegang standar ke-sahịị-an

14 Zuli Qadir, Radikalisme Agama di Indonesia, 99.

${ }^{15}$ Ibn Șalāh, Ma'rifät Anw̄à'i 'Ulūm al-Hadith, Tahquiq, Nūr al-Dīn 'Itr (Madinah: al-Maktabah al-'Ilmiyah, 1972), 10. 124.

${ }^{16}$ Syuhudi ismail, Kaidah Keșaḥịhan Sanad Hadis (Jakarta: Bulan Bintang, 1995), 
sanad hadis yang telah dikemukakan oleh Ibn Salāh. ${ }^{17}$ Dengan demikian, standar atau kriteria hadis sahi hi yang disepakati kebanyakan ulama adalah hadis yang sanadnya bersambung, seluruh periwayat dalam sanad bersifat adil, d̦ābit, terhindar dari shadh dan 'illat.

Standard ke-sahihh-an matan juga sudah ditetapkan oleh ulama sebagaimana sanad. Ulama klasik hingga kontemporer mempunyai standar ke-sahịh-an matan tersendiri dalam melakukan uji validitas, sebagaimana yang terjadi juga pada sanad hadis. Adapun standar validitas ke-sahịh-an matan hadis yang diharapkan mampu memberikan makna hadis yang kontekstual, dalam kajian ini penulis mengacu pada tujuh kaidah yang dijadikan standar dalam kajian ini, yaitu; (a). Merelevansikan dengan Alquran, (b). Membandingkan riwayat hadis Ahăd dengan riwayat hadis lainnya, (c). Membandingkan hadis satu dengan lainnya, (d). Tidak beseberangan dengan fakta sejarah, (e). Makna hadis dapat diterima oleh Akal, (f). Tidak berseberangan dengan al-usūl al-shar'iyyah dan qawā'id almuqarrarah, (g).Makna hadis tidak mengandung sesuatu yang mustahil. ${ }^{18}$

Tujuh standard ke-sahihh-an hadis tersebut dianggap peneliti mampu menghasilkan makna yang obyektif dan komprehensf tentang makna hadis yang berhubungan dengan khiläfah.

\section{Radikalisme dalam Alquran dan Sunnah}

Dalam Alquran, Allah Swt. secara tegas melarang untuk berlebihan atau melewati batas yang telah ditetapkan dalam urusan beragama, hal ini bisa dijumpai dalam surat an-Nisa' ayat 171:

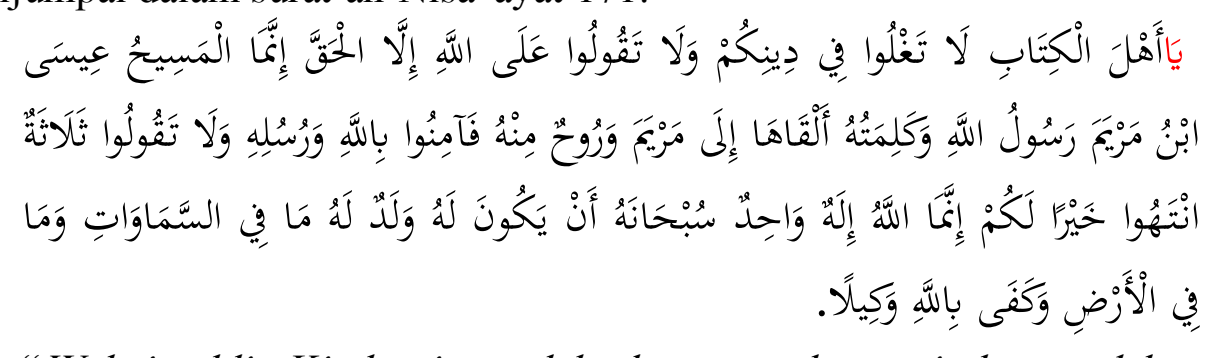

"Wahai ahli Kitab, janganlah kamu melampaui batas dalam agamamu, dan janganlah kamu mengatakan terhadap Allah kecuali yang benar. Sesungguhnya Al Masih, Isa putera Maryam itu, adalah utusan Allah dan (yang diciptakan dengan) kalimat-Nya yang disampaikan-Nya kepada Maryam, dan (dengan tiupan) ruh dari-Nya. Maka berimanlah kamu kepada Allah dan rasul-rasul-Nya dan

${ }^{17}$ Ibn Kathīr, Ikhtisar 'Ulūm al-Hadith, di jelaskan lagi oleh Ahmad Muhammad Abū Shakir, dengan judul al-Bā'ith al-Hathīth fí 'Ikhtișār Ulūm al-Hadith (Bayrūt: Dār alFikr, tth), 6-7.

${ }^{18}$ Musfir 'Azmullah Musfir al-Damini, Maqāyisisi Naqd Mutūn al-Sunnah (Saudi: tp, 1984), 115-223. 
janganlah kamu mengatakan: "(Tuhan itu) tiga", berhentilah (dari Ucapan itu). (Itu) lebih baik bagimu. Sesungguhnya Allah Tuhan yang Maha Esa, Maha suci Allah dari mempunyai anak, segala yang di langit dan di bumi adalah kepunyaan-Nya. cukuplah Allah menjadi Pemelihara."

Imam Ibn Kathïr dalam tafsirnya menyebutkan bahwa yang dimaksud dengan berlebihan dalan teks ayat tersebut adalah berlebihan dalam mengikuti dan mengamalkan ajaran agama, sebagaimana yang telah dilakukan oleh orang-orang nasrani yang menuhankan Nabi Isa a.s, padahal mereka hanya diperintahkan untuk mengimaninya sebagai Nabi, bukan Tuhan. ${ }^{19}$

Rasulullah Saw. dalam sebuah hadis yang disampaikan oleh Ibn 'Abbās ia melarang ummatnya untuk melakukan ajaran-ajaran agama secara radikal atau ekstrim;

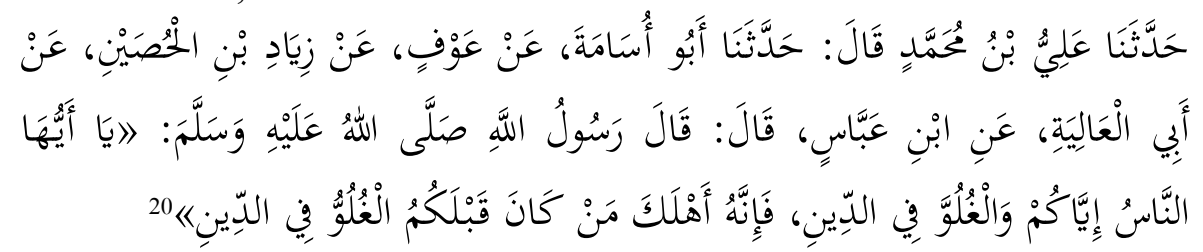

Dari Ibn 'Abbās ra, Nabi saw bersabda: "Hindarilah berlebihan dalam urusan agama, sesungguhnya sikap radikal atau berlebihan dalam beragama telah menghancurkan ummat sebelum kalian.

Historisitas (sabab al-wurud) hadis tersebut mempunyai pesan penting buat ummat beliau bahwa radikalisme muncul dan bermula dari sesuatu yang remeh atau perkara kecil, kemudian meluas ke masalahmasalah yang besar. Hal ini bisa dilihat dari redaksi hadis secara sempurna bahwa ketika Nabi saw sampai di muzdalifah dalam haji wada', beliau meminta Ibn 'Abbās untuk mengambil beberapa kerikil guna keperluan melempar jumrah di Mina, Ibn 'Abbās pun mengambilkan tujuh kerikil untuk Nabi Saw., lalu Nabi Saw. meletakkan kerikil-kerikil itu di tangannya, seraya bersabda: "orang-orang seperti mereka jauhilah". Mereka dalam redaksi hadis tersebut adalah orang-orang atau kelompok-kelompok yang radikal dalam beragama, hal ini dibuktikan dengan redaksi kalimat yang disabdakan Nabi setelah mengatakan "jauhilah orang-orang seperti mereka". Redaksi hadis di atas selengkapnya dapat dicermati dalam tulisan berikut ini;

${ }^{19}$ Abū al-Fida' Ismail Ibn Kathïr, Tafsir Ibn Katsir. Tahqiq: Muhammad Husain Syamsuddin (Bayrūt: Dār al-Kutub al-Ilmiyah, 1419), jil 2, 242.

${ }^{20} \mathrm{Abu}$ 'Abdillah Muhammad Ibn Majah, Sunan Ibn Majah. Tahqiq: Muhammad Fuad Abd al-Baqi (tt: Dār Ihya' al-Kutub al-'Arabiyyah, tt), jil 2, 1008. 


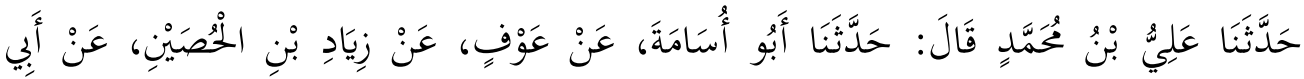

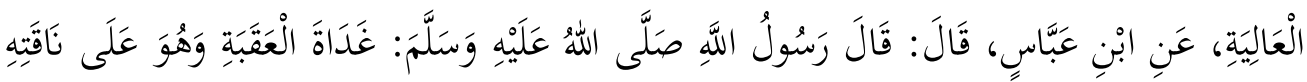

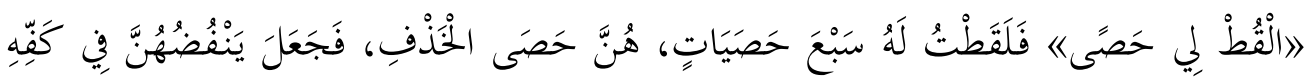

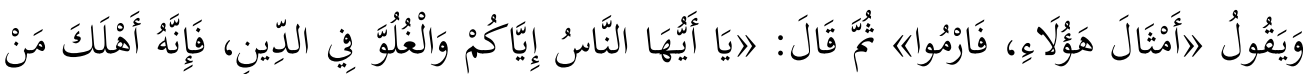

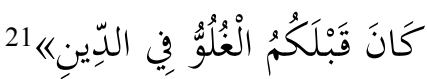

Hadis tersebut juga mempunyai makna secara tersirat bahwa janganlah beranggapan bahwa kerikil yang besar lebih utama untuk melempar jumrah daripada kerikil yang kecil. Anggapan seperti ini akan berdampak tumbuhnya sikap radikal secara perlahan. Sikap berlebihan atau radikal dalam beragama yang ditunjukkan oleh hadis tersebut menurut Ibn Taymiyyah berlaku secara umum atau universal, baik dalam urusan ibadah, muamalah dan keyakinan. ${ }^{22}$

Dalam riwayat Muslim, Nabi Saw. menegaskan bahwa binasalah orang-orang yang berlebihan atau bersikap radikal, demikian ini dapat dibaca dalam redaksi hadis berikut ini:

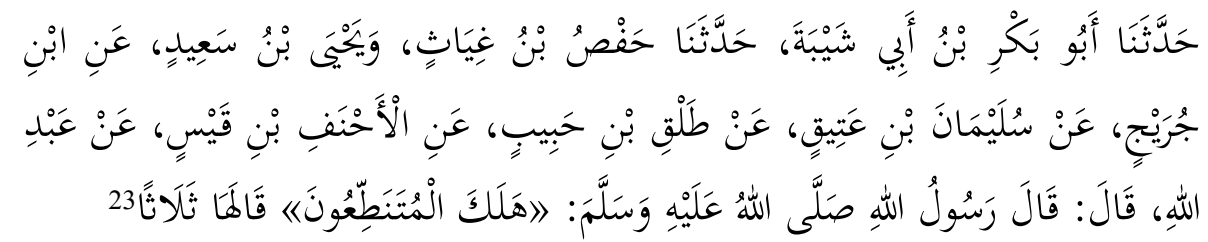

Dari Abdullah, Nabi saw bersabda: "celakalah orang-orang yang bersikap berlebihan atau radikal. Nabi Saw. mengulanginya tiga kali."

Muhammad Fu'ad Abdul Baqi dalam sumber buku yang sama (Șahịh Muslim cetakan Dār Ihyā al-Turāth al-'Arabī) menjelaskan bahwa yang dimaksud dengan kalimat "al-mutanatti'ün" adalah orang-orang atau kelompok-kelompok yang berlebihan dan melampaui batas dalam segala hal, baik dari segi ucapannya atau perbuatannya. Kiranya cukuplah kalimat 'celaka' sebagai sebuah gambaran bahwa berlebihan atau bersikap secara

${ }^{21}$ Abū 'Abdillah Mụhammad Ibn Majah, Sunan Ibn Majah. Tahqiq: Muhammad Fuad Abd al-Baqi (tt: Dār Ihya' al-Kutub al-'Arabiyyah, tt), jil 2, 1008.

22 Yusuf al-Qardhawi, al-Shahwah al-Islamiyyah Bayna al-Jumūd wa al-Tatarruf, 25.

${ }^{23}$ Muslim ibn Hajjaj al-Naysabūiri, Sahịh Muslim. Tahqiq: Muhammad Abd alBaqy (Bayrūt: Dār Ihya al-Turats al-Araby, tt), jil 4, 2055. 
radikal dalam beragama sebagai sebuah larangan yang sangat merugikan dan membawa dampak kehancuran bagi pelakunya, baik di Dunia maupun di Akhirat. Dari hadis ini dan hadis sebelumnya dapat diambil kesimpulan bahwa dari sikap radikal atau ekstrim dalam berbagai hal termasuk beragma mempunyai efek dan dampak kehancuran dan kerugian bagi pelakunya. Demikian ini dikuatkan dengan pernyatan hadis berikut;

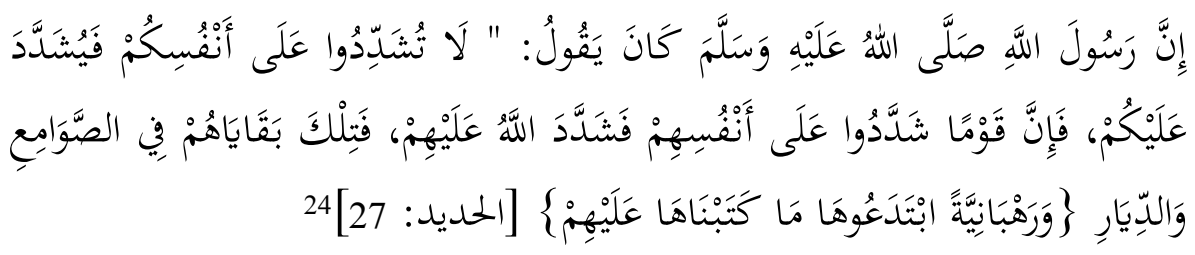

"Rasulullah saw bersabda: janganlah kalian bersikap keras terhadap diri sendiri, sehingga dietapkan ketetuan yang keras terhadap kalian, sesungguhnya terdapat suatu kaum/ kelompok yang bersikap keras kepada diri mereka sendiri, lantas ditetapkan bagi mereka ketentuan yang keras pula. Itulah peninggalan-peninggalan mereka di biarabiara dan rumah-rumah ibadah mereka; sifat rahbaniyah (beribadah layaknya rahib atau ahli agama di kalangan kaum yahudi yang mengharuskan seseorang menjauhkan diri dari semua kesenangan dan pernak-pernik kenikmatan serat kemewahan kehidupan dunia) yang mereka ciptakan sendiri yang tidak Aku (Allah Swt.) wajbkan bagi mereka."

Nabi Saw. sebagai uswah ḥasanah bagi seluruh umatnya melarang semua sahabat-sahabatnya untuk berperilaku radikal dalam beragama, sebagaimana dinyatakan dalam hadis tersebut. Nabi Saw. tidak mengajarkan berlebihan dalam menjalankan agama. Islam adalah agama yang selalu mempertimbangkan aspek-aspek kemanusiaan atau humanisme. Islam mempunyai prinsip pokok yaitu sebagai agama yang rahmatan tì al- 'àlamin dalam setiap nilai atau syariat yang telah ditetapkan. Demikian ini dapat dijumpai dalam beberapa ayat Alquran yang melarang seseorang mengharamkan sesuatu yang telah dihalalkan oleh Allah Swt. Sebagaimana firman Allah SWT dalam surat al-A'rāf ayat 31-32;

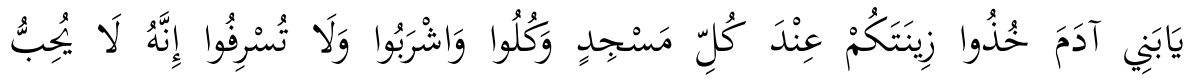

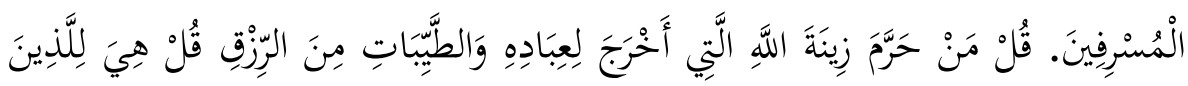

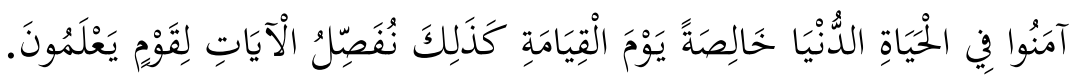

24 Abū Dāwud Sulaiman al-Sajistany, Sunan Abi Dawud, jil 4, 476.

Vol 7, No. 02, Desember 2019 
"Hai anak Adam, pakailah pakaianmu yang indah di Setiap (memasuki) mesjid[Maksudnya: tiap-tiap akan mengerjakan sembahyang atau thawaf keliling ka'bah atau ibadat-ibadat yang lain], Makan dan minumlah, dan janganlah berlebihlebihan[Maksudnya: janganlah melampaui batas yang dibutuhkan oleh tubuh dan jangan pula melampaui batas-batas makanan yang dihalalkan.]. Sesungguhnya Allah tidak menyukai orang-orang yang berlebih-lebihan. Katakanlah: "Siapakah yang mengharamkan perhiasan dari Allah yang telah dikeluarkan-Nya untuk hambahamba-Nya dan (siapa pulakah yang mengharamkan) rezki yang baik?" Katakanlah: "Semuanya itu (disediakan) bagi orang-orang yang beriman dalam kehidupan dunia, khusus (untuk mereka saja) di hari kiamat[Maksudnya: perhiasan-perhiasan dari Allah dan makanan yang baik itu dapat dinikmati di dunia ini oleh orang-orang yang beriman dan orang-orang yang tidak beriman, sedang di akhirat nanti adalah semata-mata untuk orang-orang yang beriman saja.]." Demikianlah Kami menjelaskan ayat-ayat itu bagi orang-orang yang mengetahui."

Dalam surat al-Mā'idah ayat 87-88 Allah Swt. juga berfirman;

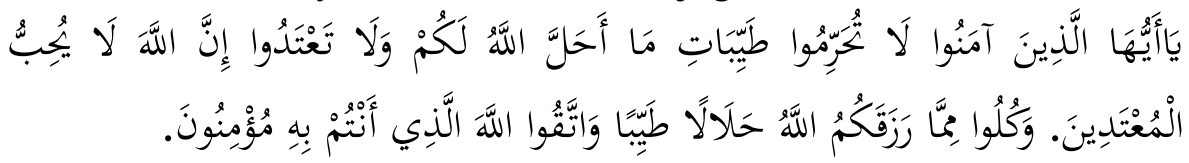

"Hai orang-orang yang beriman, janganlah kamu haramkan apa-apa yang baik yang telah Allah halalkan bagi kamu, dan janganlah kamu melampaui batas. Sesungguhnya Allah tidak menyukai orang-orang yang melampaui batas. Dan makanlah makanan yang halal lagi baik dari apa yang Allah telah rezekikan kepadamu, dan bertakwalah kepada Allah yang kamu beriman kepada-Nya."

Kedua ayat di atas menjelaskan kepada segenap umat bahwa Islam tidak melarang untuk menikmati kebaikan-kebaikan yang dihalalkan oleh Allah Swt., ayat tecrsebut bahkan melarang dan memerangi sikap berlebihan atau melampaui batas yang telah ditetapkan. Historisitas ayat tersebut menyebutkan bahwa sebagian sahabat mengatakan bahwa mereka akan memotong kemaluan mereka, meninggalkan semua kesenangan dunia dan menjalani hidup layaknay pendeta. Setelah menegetahui ungkapan mereka ini Nabi bersabda: "sesungguhnya saya puasa dan juga berbuka, shalat dan juga tidur, menikah dengan perempuan, siapa saja yang ingin menjalankan 
sunnhaku maka ia termasuk golonganku, dan siapa saja yang mengingkarinya maka ia bukan termasuk golonganku" ${ }^{25}$

Dalam riwayat yang disampaikan oleh Ibn 'Abbās dalam kitab șahịh al-Bukhari dan Muslim disebutkan bahwa sebagian sahabat Nabi bertanya kepada 'Aisyah r.a. tentang amal Nabi Saw. yang tersembunyi. Setelah mengetahui amal Nabi Saw. yang tidak nampak, maka sebagian mereka berkata bahwa mereka berkeinginan untuk tidak menikah, sebagian lagi mengatakan tidak akan tidur diatas kasur atau matras. Mengetahui perkataan mereka ini, Nabi Saw bersabda; "mengapakah ada orang-orang yang berkata seperti itu, sesungguhnya saya berpuasa dan berbuka, tidur dan bangun dan menikahi perempuan, barangsiapa yang membenci sunnahku maka ia bukan dari golonganku"26

Sunnah yang dimaksud dalam hadis di atas adalah model dan cara Nabi Saw. dalam memahami dan melaksanakan ajaran-ajaran Islam. Kedua hadis di atas telah jelas menunjukkan bahwa nilai dasar Islam adalah proporsional dan bukan radikal. Oleh karena itu apapun dan bagaimanapun sikap radikal tidak dibenarkan dalam Islam.

\section{Khalifah Dalam Al-Quran}

Khalifah berasal dari bahasa Arab yang berasal dari suku kata kha-lafa yang terdiri dari tiga huruf. Kalimat yang berasal dari kata kha, la, fa tersebut dalam berbagai macam bentuk dan maknya terulang sebanyak 127 kali dalam Alquran. ${ }^{27}$ Dari 127 kali pengulangan, kata tersebut mempunyai 12 shighat yang tercantum dalam Alquran. ${ }^{28}$ Pembahasan ini akan memfokuskan pada kata Khalifah sebagai bentuk tunggal dan khalā'ifkhulafa' keduanya merupakan bentuk jamak dari kata khalifah yang secara bahasa berarti pemimpin. Kata khalifah dan bentuk jamaknya dalam Alquran terulang sebanyak sembilan kali.

Ibn Mandhūr memaknai kata khalifah sebagai orang yang menggantikan orang sebelumnya, jamak dari khalifah adalah khalā'if atau khulafă ${ }^{29}$ Al-Marāghì dalam tafsirnya menyebutkan bahwa maksud dari khalifah adalah orang yang menggantikan Allah Swt. dalam menjalankan perintah-perintah-Nya dan urusan-urusan-Nya di antara manusia. ${ }^{30}$ Al-

${ }^{25}$ Abū al-Fida' Ismail Ibn Katsir, Tafsir Ibn Katsir, jil 3, 152

26 Muhammad ibn Ismail al-Bukhary, Saḥịh al-Bukhary. Tahqiq: Muhammad Zahir (tt: Dār Thuu al-Najah, 1422H), jil 7, 2.

${ }^{27}$ Muhammad Fuad Abd Al-Bāqī. Al-Mu'jam al-Mufahras li al-Fadzi al-Qur'an (Indonesia:Maktabah Dakhlan. T th), 303-306.

${ }^{28}$ Abd Al-Rahim, "Khalifah dan Khilafah dalam al-Qur'an,” Jurnal: Hunafa: Jurnal Studi Islamika Vol 9. No 1 (2012): 22.

${ }^{29}$ Ibn Mandhūr Al-Anshary, Lisān al-'Arab (Bayrūt: Dār al-Shadir, 1414), 84.

${ }^{30}$ Ahmad ibn Mustafa Al-Maraghì, Tafsìr al-Maräghī (Mesir: Maktabah Mustafa al-Bab al Halaby. 1946). 77. 
Zuhayli dalam tafsirnya mendefinisikan khalifah dengan orang yang menggantikan orang sebelumnya dalam hal menjalankan dan menegakkan hukum, al-Zuhayli menegaskan bahwa khalifah dalam ayat tersebut (Q.S alBaqarah: 30) adalah Nabi Ādam A.s. ${ }^{31}$ Penafsiran al-Zuhayli ini mirip dengan pendahulunya yaitu al-Zamakhsyari yang mengatakan bahwa khalifah dalam ayat tersebut adalah Nabi Ādam, khalifah sendiri secara bahasa bermakna pengganti dari selainnya. ${ }^{32}$ Al-Thabari dalam tafsirnya menyebutkan bahwa raja atau penguasa tertinggi bisa disebut sebagai khalifah, karena ia menggantikan raja sebelumnya dan menempati posisinya. ${ }^{33}$ Dari beberapa penafsiran di atas tentang makna khalifah, dapat disimpulkan bahwa khalifah yang dimaksud dalam ayat tersebut adalah Nabi $\bar{A}$ dam as, sedangkan makna khalifah secara bahasa adalah orang yang menggantikan orang sebelumnya atau selainnya dalam urusan tertentu.

Penafsiran makna khalifah sebagai pengganti dikuatkan oleh ayat ke 28 surat Șād sebagaimana yang ditulis oleh al-Wahidi dalam tafsirnya. ${ }^{34}$ AlQurțubi juga tidak berbeda dengan mufassir sebelumnya yang memberikan makna khalifah sebagai pengganti dari sebelumnya yaitu malaikat atau selain malaikat. ${ }^{35}$ Semua mufassir yang disebutkan di atas dalam memberikan makna khalifah pada surat al-Baqarah ayat 2, konsisten terhadap pemaknaan khalifah pada surat Șād ayat 28. Dari beberapa penafsiran arti kata khalifah para ahli tafsir tidak mempunyai perbedaan signifikan dalam memberikan arti khalifah yaitu pengganti Allah Swt. atau Malikat atau orang sebelumnya atau lainnya dalam menegakkan hukum atau urusan tertentu di Bumi.

Kata khalifah yang terdapat di dua surat tersebut seakan-akan menjadi satu kesatuan yang saling melengkapi. Hal ini dapat dilihat dalam penafsiran yang disampaikan oleh al-Qurtubỉ tentang ke-khalifah-an Nabi Dāwud A.s. dalam tafsirnya menyebutkan bahwa Nabi Dāwud diperintahkan oleh Allah Swt. untuk menjadi khalifah dengan tujuan memerintahkan yang baik dan melarang yang buruk, sebagai pengganti dari Nabi-Nabi, atau orang-orang baik sebelumnya. Kata khalifah digunakan dua kali dalam Alquran dengan bentuk single mempunyai arti pengganti sebelumnya dalam

${ }^{31}$ Wahbah Al-Zuhay帀i, Tafsir Munir (Bayrūt: Dār al-Fikr, 1418), 124.

32 Al-Zamakhsyary, Al-Kasyaf an Haqaiq Ghawamidh al-Tanzīl (Bayrūt: Dār alKitab al-'Araby, 1407), 124

${ }^{33}$ Muhammad ibn Jarir Al-Thabari, Jami' al-Bayan fi Ta'wil al-Qur'an. Editor: Ahmad Muhammad Syakir (Ttp, Muassasah al-Risalah, 2000). 449.

${ }^{34}$ Abū Hasan Al-Wahidi, Al-Wajiz fi Tafsir al-Kitab al-'Aziz (Bayrūt: Dār alQalam, 1415), 922.

${ }^{35}$ Abū 'Abdillah Syamsuddin al-Qurțūbī, Al-Jami' li Ahkam al-Qur'an. Editor: Ahmad al-Barduni (Kairo: Dār al-Kutub al-Misriyyah, 1964). 263. 
hal menegakkan hukum, menjalankan urusan-urusan tertentu yang lebih bersifat kekuasaan. Dalam hal ini Kekuasaan yang dimaksud cakupannya luas, mencakup Dunia sebagaimana Allah sebutkan dengan kata Bumi dalam surat al-Baqarah. Cakupan khalifah juga bisa diartikan dengan ruang lingkup yang sempit dan menjangkau komunitas tertentu, hal ini sebagaiman petunjuk dari surat Șad ayat 28.

\section{Kontekstualitas Matan Hadis Khiläfah}

Makna hadis dari semua hadis-hadis yang tercantum dalam kitab Nizāam al-Hukm fî̀ al-Islām bab al-Khilāfah sebagaimana yang telah disebutkan di atas, bila dicermati mengerucut pada dua tema penting, yaitu tentang baiat dan larangan menentang kepemimpinan pimpinan yang sah atau perintah tunduk patuh terhadap pimpinan.

Baiat berasal dari bahasa arab yang mempunyai akar kata baya'a, dalam Alquran juga ditemui kata yang berderivasi baya'a. Baya'a secara bahasa atau etimologi mempunyai luas, di antaranya adalaha saling jabat tangan telah dilangsungkannya kesepakatan jual beli, berjanji setia untuk patuh dan taat, ucapan sumpah untuk setia, pengangkatan, dan penobatan (pemimpin). ${ }^{36}$ Baiat secara bahasa oleh Ibn Mandhūr dikatakan sebagai ikatan janji. ${ }^{37}$ Berjabat tangan setelah terjadinya kesepakatan antara kedua belah pihak merupakan sebuah tradis orang Arab sejak dahulu, sebagai ganti dari stempel, cap, cincin atau tanda tangan.

Baiat secara istilah atau terminologi mempunyai makna berjanji untuk taat dan patuh terhadap pimpinan, baik atas kebijkannya yang disenangi atau yang tidak disenangi. ${ }^{38}$ Baiat digunakan untuk mengukuhkan kekuasaan baik secara khusus melalui kelompok tertentu, ataupun secara umum oleh umat. Konsep baiat biasanya identik dengan kesepakatan politik. Merujuk kepada pendapat Ibn Taymiyyah bahwa baiat juga bisa diaplikasikan pada hal-hal parsial dari syariah selama tidak bertentangan dengan prinsip patuh dan tunduk kepada pimpinan. Baik perjanjian tersebut kepada dirinya sendiri untuk selalu berkomitment taat kepada Allah, atau antara dirinya dengan orang lain, selama tidak bertentangan terhadap syariat Allah $^{39}$.

Beberapa paparan di atas tentang makna baiah, dapat diambil benang merah bahwa baiah dalam konteks hadis tersebut yaitu kerelaan hati dan kesetiaan janji untuk selalu patuh dan taat terhadap perintah dan kebijakan pemimpin, baik yang disenangi ataupun yang tidak disenangi. Dalam

${ }^{36}$ TIM UIN Syarif Hidayatulloh, Ensiklopedia Islam (Jakarta: Jambatan, 1992), 52.

${ }^{37}$ Ibn Mandhür, Lisan al-Arab, 275

${ }^{38}$ Warson Munawwir, Kamus al-Munawwir(Yogyakarta: PP Krapya, 1984), 135

39 Ibn Taymiyah, Risalah Baiah, terj. Ahmad Tarmudzi (Jakarta: Pusat Tauhid, 2002), 23. 
konteks Indonesia, pemimpin yang dimaksud adalah presiden hingga ketua RT di sebuah desa.

Bai'ah pada masa Nabi Saw. hanya ada tiga saja yang terekam sejarah, yaitu bai'ah Aqabah I (621 M), bai'ah Aqabah II (622M), bai'ah alRiḍwān atau lebih dikenal dengan perjanjian Hudaybiyyah $(6 \mathrm{H})$. Bai'ah yang pertama, dilakukan oleh penduduk Madinah atau Yathrib ketika bertemu Nabi di Makkah, mereka berjumlah 12 orang laki-laki dan 1 orang perempuan. Mereka berbai'ah dihadapan Nabi Saw. untuk bersyahadat dan tidak melakukan perbuatan yang dilarang oleh Allah Swt. dan Rasulullah Saw. ${ }^{40}$ Bai'ah yang kedua diikuti oleh 2 perempuan dan 73 laki-laki, isi dari bai'ah ini yaitu berjanji untuk setia rela berkorban untuk jihad dan membela Rasulullah Saw. dan Nabi pun berjanji untuk selalu membela agamanya Allah Swt. tanpa pamrih..$^{41}$ Bai'ah yang ketiga yaitu perjanjian damai antara Nabi dengan penduduk Makkah yang mengira Nabi dan kaum muslimin datang ke Makkah untuk berperang. ${ }^{42}$

Melihat penerapan bai'ah pada masa Nabi Saw., bai'ah tidak hanya mempunyai makna untuk setia patuh kepada pemimpin, tetapi juga ikrar atau kesepakatan perjanjian antara kedua belah pihak. Bai'ah yang pertama juga tidak berhubungan dengan kepemimpinan, akan tetapi penekanannya lebih pada taat kepada Allah Swt. Kata-kata bai'ah digunakan oleh Allah Swt. dalam Alquran yang mempunyai makna berjanji untuk taat kepada Allah Swt. sebagaimana dalam Q.S. 60: 12;

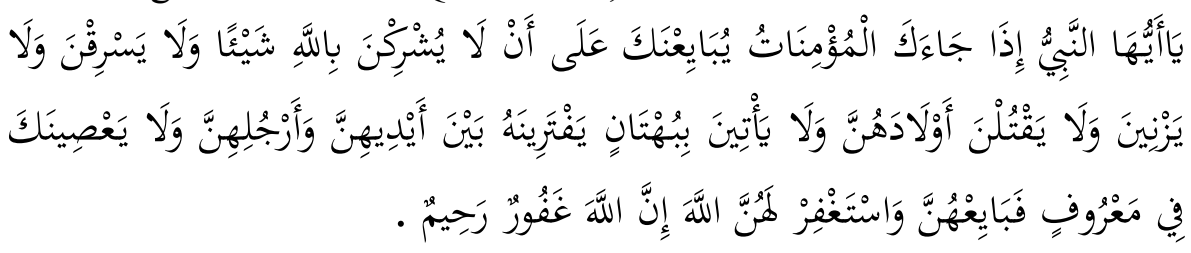

"Hai Nabi, apabila datang kepadamu perempuan-perempuan yang beriman untuk Mengadakan janji setia, bahwa mereka tiada akan menyekutukan Allah, tidak akan mencuri, tidak akan berzina, tidak akan membunuh anak-anaknya, tidak akan berbuat Dusta yang mereka ada-adakan antara tangan dan kaki mereka [Perbuatan yang mereka ada-adakan antara tangan dan kaki mereka itu Maksudnya ialah Mengadakan pengakuan-pengakuan palsu mengenai hubungan antara pria dan wanita seperti tuduhan berzina, tuduhan bahwa anak si Fulan bukan anak suaminya dan sebagainya] dan tidak akan

40 MT Misbah Yazdi, Iman Semesta Merancang Piramia Keyakinan. Terj. Ahmad Marzuki Amin (Jakarta: Al-Huda, 2005), 294.

${ }^{41} \mathrm{~J}$ suyuti Pulugan, Prinsip-prinsip Pemerintahan dalam piagam Madinah, (Jakarta: Raja Grafindo, 1994), 280.

$42 \mathrm{~J}$ suyuti Pulugan, Prinsip-prinsip Pemerintahan dalam piagam Madinah, 283. 
mendurhakaimu dalam urusan yang baik, Maka terimalah janji setia mereka dan mohonkanlah ampunan kepada Allah untuk mereka. Sesungguhnya Allah Maha Pengampun lagi Maha Penyayang."

Allah SWT juga berfirman dalam Q.S. 9: 111 mengenai bai'ah tentang pengorbana atas nama Allah Swt;

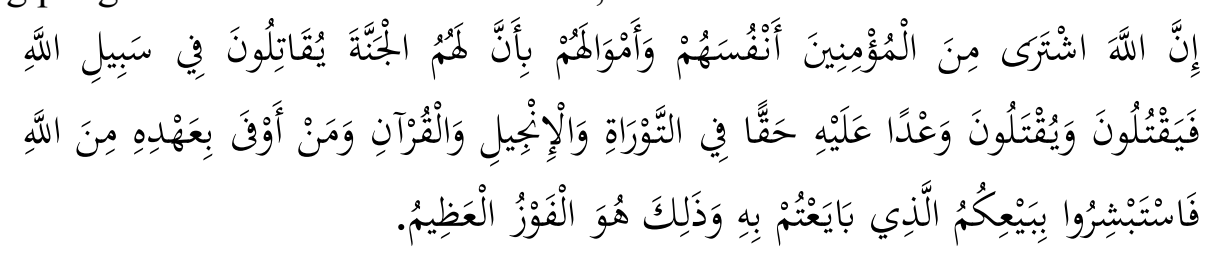

"Sesungguhnya Allah telah membeli dari orang-orang mukmin diri dan harta mereka dengan memberikan surga untuk mereka. mereka berperang pada jalan Allah; lalu mereka membunuh atau terbunuh. (Itu telah menjadi) janji yang benar dari Allah di dalam Taurat, Injil dan Al Quran. dan siapakah yang lebih menepati janjinya (selain) daripada Allah? Maka bergembiralah dengan jual beli yang telah kamu lakukan itu, dan Itulah kemenangan yang besar."

Kata bai'ah juga Allah sampaikan pada surat al-Fath yang mempunyai implikasi makna bahwa bai'ah yang dilakukan seseorang sesungguhnya erat kaitannya dengan janji dan keteguhan hati untuk tidak melanggarnya. Melanggar bai'ah sama saja dengan melanggar dan durhaka kepada Allah Swt. Sebagaimana ayat berikut ini;

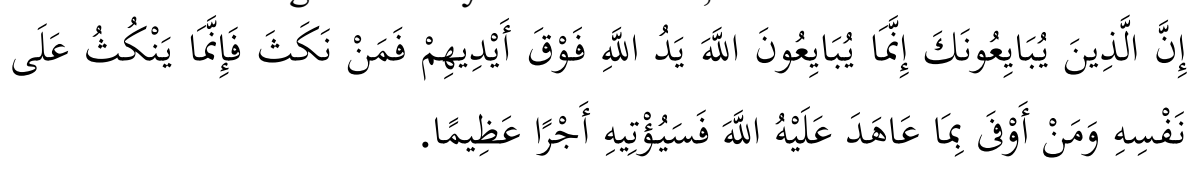

"Bahwasanya orang-orang yang berjanji setia kepada kamu Sesungguhnya mereka berjanji setia kepada Allah, ${ }^{43}$ tangan Allah di

${ }^{43}$ Pada bulan Zulka'dah tahun keenam Hijriyyah Nabi Muhammad Saw. beserta pengikut-pengikutnya hendak mengunjungi Mekkah untuk melakukan 'umrah dan melihat keluarga-keluarga mereka yang telah lama ditinggalkan. Sesampai di Hudaibiyah beliau berhenti dan mengutus Utsman bin Affan lebih dahulu ke Mekah untuk menyampaikan maksud kedatangan beliau dan kamu muslimin. mereka menanti-nanti kembalinya Uthmān, tetapi tidak juga datang karena Utsman ditahan oleh kaum musyrikin kemudian tersiar lagi kabar bahwa Utsman telah dibunuh. karena itu Nabi menganjurkan agar kamu muslimin melakukan bai'ah (janji setia) kepada beliau. merekapun Mengadakan janji setia kepada Nabi dan mereka akan memerangi kamu Quraisy bersama Nabi sampai kemenangan tercapai. Perjanjian setia ini telah diridhai Allah sebagaimana tersebut dalam ayat 18 surat ini, karena itu disebut Bai'atur Ridwan. Bai'atur Ridwan ini menggetarkan kaum musyrikin, sehingga mereka melepaskan Utsman dan mengirim utusan untuk Mengadakan Perjanjian damai dengan kaum muslimin. Perjanjian ini terkenal dengan Ṣulh al-Ḥudaybiyah. 
atas tangan mereka, ${ }^{44}$ Maka Barangsiapa yang melanggar janjinya niscaya akibat ia melanggar janji itu akan menimpa dirinya sendiri dan Barangsiapa menepati janjinya kepada Allah, Maka Allah akan memberinya pahala yang besar."

Dalam beberapa literatur hadis yang lain, dijumpai beberapa istilah bai'ah yang tidak hanya berlaku pada konteks rakyat dan pemimpin, sebagaimana hadis-hadis berikut;

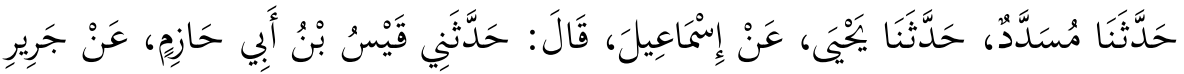

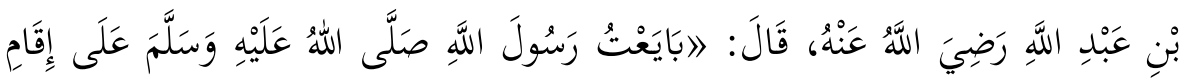

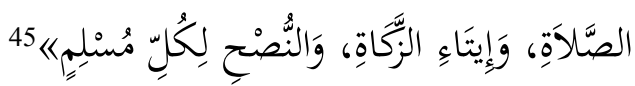

Artinya; saya (Jarir ibn Abdillah) berikrar kepad Rasulullah Saw. untuk selalu melaksanakan shalat, menunaikan zakat dan selalu menasehati kepada sesama muslim.

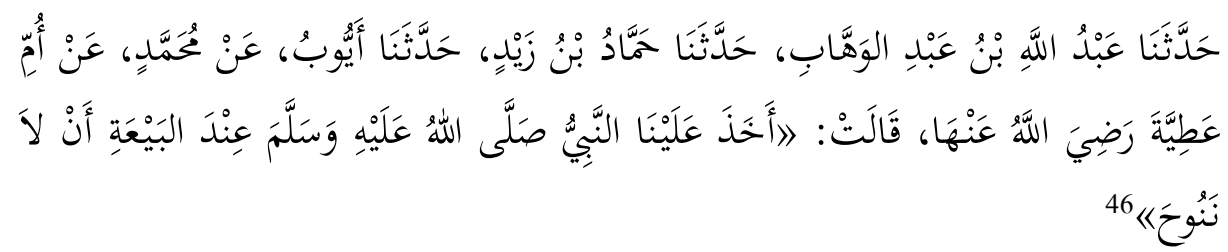

Artinya; Rasulullah saw telah mengambl janji kami untuk tidak lagi meratapi orang yang telah meninggal.

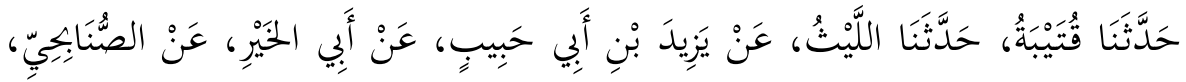

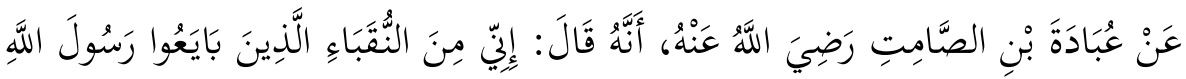

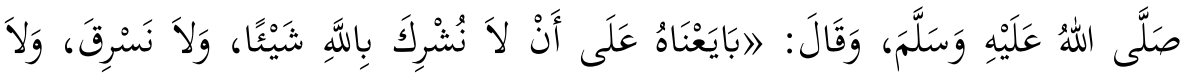

44 Orang yang berjanji setia biasanya berjabatan tangan. Caranya berjanji setia dengan Rasul ialah meletakkan tangan Rasul di atas tangan orang yang berjanji itu. Jadi maksud tangan Allah di atas mereka ialah untuk menyatakan bahwa berjanji dengan Rasulullah sama dengan berjanji dengan Allah. Jadi seakan-akan Allah di atas tangan orangorang yang berjanji itu. hendaklah diperhatikan bahwa Allah Maha suci Dari segala sifatsifat yang menyerupai makhluknya.

${ }^{45}$ Muhammad ibn Ismail al-Bukhari, Sahịh al-Bukhari, Vol 3, 189.

${ }^{46}$ Muhammad ibn Ismail al-Bukhari, Sahịh al-Bukharī. Vol 2, 84. 


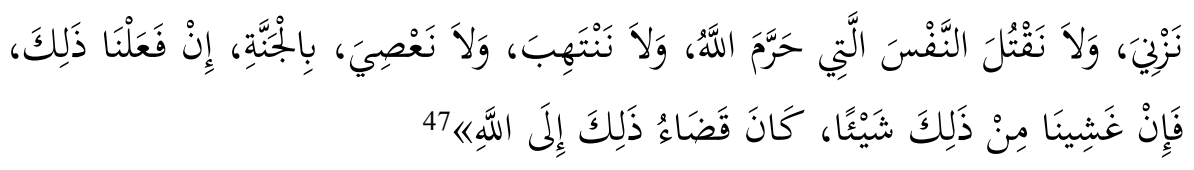

Diriwayatkan dari Ubadah ibn Shamit, ia merceritakan sesungguhnya ia termasuk bagian dari pemimpin kaumnya yang berikrar janji kepada Rasulullah saw untuk tidak menyukutukan Allah $S$ wt., tidak mencuri, tidak berzina, tidak membunuh, tidak merampas hak orang lain, tidak bermaksiat kepada Allah, jika memang dia dan pemimpin lainnya menaati janjinya, maka ia akan mendapatkan surga, dan jika melanggar janjinya maka ia akan mendapatkan murka Allah $S_{W t}$.

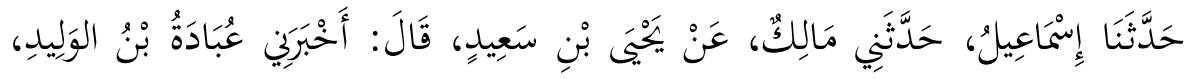

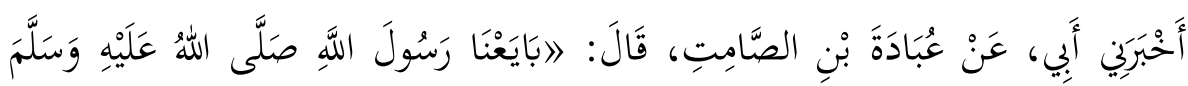

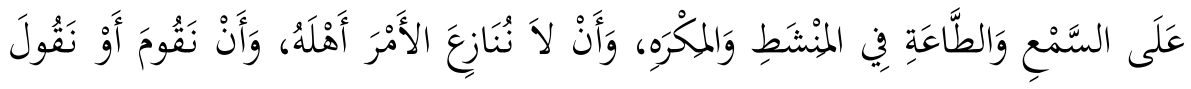

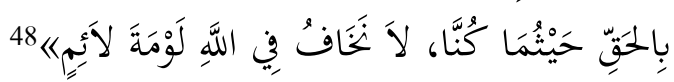

Artinya; kami berjanji (berbai'ah) kepada Rasulullah Saw. untuk selalu patuh dan taat baik di kala senang ataupun susah. Kami tidak akan menentang pemimpin yang sah, dan selalu berbicara yang benar dimanapun kami berada, kami tidak takut cacian orang yang mncaci selama kami berada di jalan Allah Swt.

Berdasarkan beberapa hadis tentang bai'ah di atas, sesungguhnya kata bai'ah tidak hanya digunakan pada konteks janji setia akan kepatuhan rakyat kepada pemimpin, tetapi ikrar untuk mematuhi apa yang sudah disepakati oleh kedua belah pihak, baik dala urusan Agama ataupun urusan dunia, baik yang universal ataupun yang parsial. Para sahabat pun tidak sama dalam ucapan bai'atnya kepada Rasulullah Saw., kecuali mereka mengucapkannya dalam kepentingan dan kondisi yang sama. ${ }^{49}$

Kontekstualitas hadis pertama dalam kitab Nizām al-Hukm fí alIslām bab al-Khiläfah, muncul ketika Abdullah Ibn 'Umar melihat masyarakat Madinah tidak menerima dan juga tidak mematuhi serta tidak mengakui Yazid ibn Mu'awiyah sebagai pemimpin terpilih setelah dinyatakan resmi sebagai pemimpin yang baru di Madinah. Masyarakat Madinah kacau dan mempunyai kelompok-kelompok sendiri mengenai pemimpin. Kaum Anșar mengangkat 'Abdullāh ibn Handhalah sebagai

${ }^{47}$ Muhammad ibn Ismail al-Bukhari, Sahịh al-Bukharì, Vol 5, 55

${ }^{48}$ Muhammad ibn Ismail al-Bukhari, Sahịh al-Bukharīi, Vol 9, 77 2001), 93.

49 Abdul Qadir Baraja, Gambaran Global Pemerintahan Islam (Surabaya: RAP, 
pemimpin, sedangkan kaum Quraisy menjadikan 'Abdullāh ibn Muṭi' sebagai pemimpin, Kaum Muhājirīn mengangkat Ma'qil ibn Sinān sebagai pemimpin. Melihat keadaan seperti ini Ibnu 'Umar mendatangi Abdullāh ibn Muți' dan menyampaikan hadis tersebut, demikian ini bisa dilihat dalam redaksi hadis lengkap di atas, diperkuat dengan riwayat yang dinukil oleh imam ibn al-Jawzì dalam kitabnya. ${ }^{50}$ Imam Nawāwi menjelaskan bahwa yang dimaksud dalam hadis (لا حجة له) yaitu amalnya tidak berguna baginya dan tidak diterima semua alasan yang dikemukakannya. ${ }^{51}$ Maksud dari makna hadis (meninggal seperti matinya orang jahiliyyah) menurut Ibn Hajar bukanlah meninggal dalam keadaan kafir, melainkan meninggal seperti keadaannya orang jahiliyyah yang meninggal dalam keadaan tidak mengetahui imam atau pemimpin yang harus ditaati. ${ }^{52}$ Hadis tersebut menekankan pentingnya taat kepada pemimpin dan larangan untuk mengkudeta pemimpin yang sah. Menjadi kelompok oposisi dari pemimpin yang sah dengan melakukan tindakan-tindakan yang merugikan dan membawa dampak buruk bagi masyarakat secara umum serta dapat mengancam kedaulatan dan persatuan negara merupakan perbuatan yang dilarang oleh Rasulullah. Demikian ini, bisa dilihat dari hadis lain berikut ini;

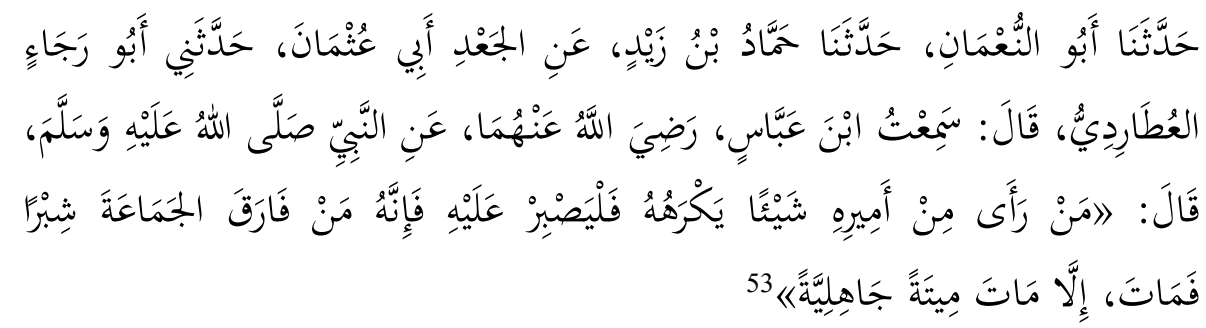

Siapapun yang melihat dari pemimpinnya sesuatu yang tidak disenanginya, maka hendaknya ia bersabar, sesungguhnya barang siapa yang keluar dari barisan resmi kepemimpinan yang sah satu jengkal saja, maka jikalau ia meninggal, ia meeninggal dalam keadaan seperti meninggalnya orang jahiliyyah.

Ibnu Hajar menyampaikan bahwa Ulama telah sepakat berdasarkan hadis tersebut tentang kewajiban semua rakyat atau masyarakat mematuhi pemimpin yang terpilih secara sah, mentaatinya jelas lebih baik daripada

${ }^{50}$ Muhammad ibn al-Jauzi, Kashfu al-Mushkil min Hadis al-Sahịhain. Tahqiq: Ali Husain al-Bawwab (Riyadh: Dār al-Watan), Vol 2, 596

${ }^{51}$ Muhammad ibn Syaraf al-Nawawi, Sharh Sahịh Muslim (Bayrūt: Dār Ihya alTurats al-Araby, 1392), Vol 12, 240.

${ }^{52}$ Ibn Hajar al-'Asqalany, Fath al-Bary. Tahqiq: Muhammad Fuad Abd al-Baqy (Bayrūt: Dār al-Ma'rifah, 1379), Vol 13, 7.

${ }^{53}$ Muhammad ibn Ismail al-Bukhari, Sahịh al-Bukharì, Vol 9, 47. 
membangkangnya, karena dengan tidak mematuhinya dan keluar dari barisannya, akan menimbulkan kekacauan bahkan pertumbahan darah. Demikian ini jelas mafsadahnya lebih besar daripada maslahahnya. ${ }^{54}$

Hadis tersebut memberikan pesan yang sangat jelas, bahwa mentaati perintah pemimpin adalah sebuah kewajiban, selama tidak memerintah keburukan dan maksiat kepaa Allah Swt. Secara verbal disampaikan oleh Nabi Saw. bahwa mengikuti perintah pemimpin baik yang sesuai dengan pendapat kita ataupun tidak, karena tidak mentaati perintah pemimpin akan membawa kekacauan dan malapetaka kerugian yang besar kepada masyarakat luas. Mentaati perintah pemimpin baik atas perintahnya yang cocok dengan keinginan kita atau yang tidak cocok, sebagaimana yang disampaikan leh baginda Nabi tercinta dalm hadi syang lain berikut ini;

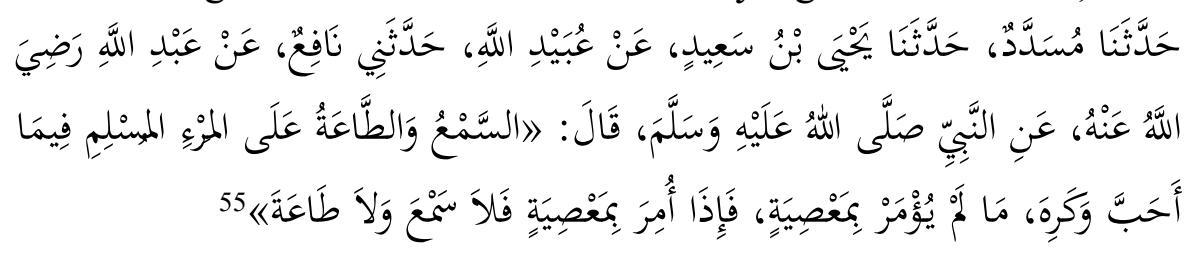

Setiap muslim wajib patuh terhadap pimpinan baik perintah yang disukai atau yang tidak disenangi, selama tidak diperintahkan untuk melakukan maksiat. Jika diperintahkan untuk maksiat maka tidak ada kewajiban untuk mentaatinya.

Hadis di atas membantah argumentasi yang mengatakan tidak wajib mematuhi perintah pimpinan jika perintahnya tidak ada dalilnya atau melakukan perintah yang tidak diperintahkan oleh Allah Swt., seperti perintah untuk mentaati rambu-rambu lalu lintas, mengibarkan dan hormat kepada bendera merah putih, mencatatkan diri di kantor pemerintahan sipil dsb. Selama perintah pimpinan tidak menabrak aturan aturan Allah dan tidak ada unsur maksiat, maka perintah pimpinan wajib dipatuhi.

\section{SIMPULAN}

Hadis-hadis yang dinukil dalam kitab Niẓām al-Hukm fỉ al-Islām bab al-Khiläfah, tidak ada kaitannya dengan kewajiban mendirikan khiläfah sebagai sebuah sistem dalam pemerintahan resmi sebuah negara. Bai'at yang tercantum dalam hadis-hadis tersebut tidak dapat dimaknai sebagai kewajiban untuk berbai'at kepada imam atau pemimpin khalifah seperti yang dimaksudkan oleh HTI, karena penggunaan kata bai'at mempunyai makna atau arti luas sebagai suatu ikatan janji untuk saling mematuhi sebuah kesepakatan yang telah dibuat.

${ }^{54}$ Ibn Hajar al-'Asqalany, Fath al-Barī. Vol 13, 7.

${ }^{55}$ Muhammad ibn Ismail al-Bukhari, Sahịh al-Bukharì, Vol 9, 63. 
Kewajiban rakyat untuk patuh dan taat kepada pemimpin, merupakan sebuah kesepakatan ulama sejak masa Nabi Saw. hingga sekarang, dalam konteks indonesia pemimpin sebuah negara termasuk presiden hingga ketua RT dalam lingkungan desa harus dipatuhi dan dilaksanakan semua kebijakannya baik senang ataupun tidak. Kelompok HTI masuk dalam kategori tidak melaksanakan pesan hadis Nabi Saw tersebut, karena tidak mematuhi kebijakan pemimpin untuk menerima pancasila sebagai landasan sebuah negara.

\section{DAFTAR PUSTAKA}

Al-Adabī, Ṣalahuddin ibn Aḥmad. Manhaj Naqd al-Matn. Bayrūt: Dār alĀfàq al-Jadidah, 1983.

Al-Albānì, Abū 'Abd al-Raḥmān Nāṣir al-Dīn. Silsilat al-Aḥāitith alMauḍūah wa al-Ḍa'îfah. Riyāḍ: Dār al-Ma'ārif, 1992.

Al-Anșarì, Jamāluddīn. al-Lubāb fi al-Jām'I bayna al-Kitāb wa al-Sunnah. Bayrūt: Dār al-Qalam, 1994.

Al-Aṣfahāni, Al-Rāghib. Mu'jam Mufradāt al-Fāạ Alquran. Libanon: Dār alFikr, t,tp.

Al-Aṣfahāni, Al-Rāghib. Mu'jam Mufradāt li al-Fādzi al-Qur'ān. Bayrūt: Dār al-Fikr, tt

Al-Bāqi, Muḥammad Fuad 'Abd. al-Mu'jam al-Mufahras li al-Fāz al-Qur'ān. t,t: Där al-Fikr, 1992.

Al-Bayhaqì, Abu Bakar Ahmad Ali. al-Sunan al- Kubrā. India: Majlis Dāirat al-Ma'ārif al-Nidhzāmiyyah al-Kāinah, 1344H, t,tp. . al-Sunan al-Kubra. India: Majlis Dairah al-Ma'arif al-Nidhamiyyah, 1344H. II, 484.

Al-Bantani, Nawawi. Uqūd al-Lujayn Fì Bayāni al-Huqūqq al-Zawjayn. Surabaya: Hidayah, tt.

Al-Būtịi, Muḥammad Sa'ỉd Ramaḍān. al-Qaḍàyā al-Fiqhiyyah al-Mu'asirah. Damaskus: Dār al-Farabi, 1994.

Al-Dahlawī, Shah Waliyullah. Hujjatullāh al-Bālighah. Bayrūt: Dār alMa'rifah, t,tp.

Al-Daminī, Musfîr 'Azmullāh Musfīr. Maqāyīsi Naqd Mutūn al-Sunnah. Saudi: tp, 1984.

Al-Dasuqi, Muḥammad ibn Aḥmad. Al-Sharḥu al-Kabir. Mesir: Maṭba'ah alBāb al-Ḥalabi, t.tp.

Al-Dhahabī, Husayn. al-Isräiliyāt fî̀ al-Tafsìir wa al-Hadith. Kairo: Maktabah Wahbah, ttp.

Alfian. Muhammadiyah: The Political Behaviourof a Muslim Modernist Organitatin under Dutch Colonialism. Yogyakarta: Gajah Mada University Press, 1989. 
Ali, Sayyed Amir. The Spirit of Islam a History of The Evolutionand Ideals of Islam With a Life Withof Tehe Prophet. Delhi: al- Idarah alAdbiyyah, 1922.

Alwisol. Psikologi Kepribadian. Malang: UMM Press, 2012.

Amal, Taufik Adnan. Islam dan Tantangan Modernis: Studi Atas Pemikiran Fazlur Rahman. Bandung: Mizan, 1989.

Al-Anșārì, Ibn Mandhūr. Lisan al-'Arab Bayrūt: Dar al-Shadir, 1414.

Anwar, Imam Basyari. Kamus Lengkap Indonesia-Arab. Kediri: Lembaga Pondok Pesantren Al-Basyari, 1987.

Asyari, Suaidi. Nalar Politik $N U$ \& Muhammadiyah. Yogyakarta: Lkis, 2009.

Atiyatullah, Ahmad. al-Qāmūs al-Islāmi. Kairo: Maktabah al-Nahḍah alMișriyyah, 1980.

Azami, Muhammad Mușțafa. Hadis Nabawi dan Sejarah Kodifikasinya, terj. Ali Mustafa Ya'kub. Jakarta: Pustaka Firdaus, 1994. . Metodologi Kritik Hadis. Terj. A. Yamin. Jakarta: Pustaka Hidayah, 1992.

Badruddin. "Pandangan Peziarah Terhadap Kewalian Kyai Abdul Hamid Bin Abdullah Bin Umar Basyaiban Pasuruan Jawa Timur: Perspektif Fenomenologis". (Ringkasan Disertasi: IAIN Sunan Ampel Surabaya, 2011)

Berger, Peter L. The Sosial Reality of Religion. England: Penguin Book Ltd, Harmonsdsworth, Middlesex, 1973.

Bruinessen, Marvin van. NU, Tradisi, Relasi-Relasi Kuasa, Pencarian Wacana Baru. Yogyakarta: Lkis, 1994.

Bungin, Burhan. Metode Triangulasi dalam Analisis Data Kajian Kualitatif. Jakarta: Radja Grafindo Persada, 2003.

C. Bogdan, Robert dan Sari Knopp Biklen. Qualitative Research in Education: an Introduction to Theory and Methods. Boston: Allyn and Bacon, 1998.

Cambridge Advanced Learner's Dictionary. Third Edition. Cambridge: Cambridge University Press.

Channa AW, Liliek. Memahami Makna Hadis Secara Tekstual dan Kontekstual, Jurnal Ulumuna, Volume XV Nomor 2 Desember 2011.

Departemen Penerangan. Sejarah Pembentukan dan Perkembangan Boedi Utomo. Jakarta: Direktorat Publikasi, Direktorat Jendral Pembinaan Pers dan Grafika, 1995.

Depdikbud RI. Kamus Besar Bahasa Indonesia. Jakarta: Balai Pustaka 1988. Efendi, Satria. Ushul Fiqh. Jakarta: Kencana, 2005.

Engineer, Asghar Ali. Hak-Hak Perempuan dalam Islam, terj. Farid Wadji dan Cici. Yogyakarta :LSPPA Yayasan Parakarsa , 1994. 
Fuaida, Ida. Konsepsi Khilāfah Dalam Alquran. Surabaya: IAIN Sunan Ampel, 1997.

Ibn 'Arif, Hatim. al-Takhrīj wa Dirasāt al-Asānid. Maktabah Syamilah.

Ibn Kathïr. Ikhtiṣar 'Ulüm al-Hadith, di jelaskan lagi oleh Ahmad Muhammad Abu Shakir, dengan judul al-Bā'ith al-Hathīth fi 'Ikhtișār Ulūm al-Hadith, Bayrūt: Dār al-Fikr, tth.

Ibn Șalāḥ. Ma'rifăt Anw̄a'ì 'Ulūm al-Hadith, Taḥqiq, Nūr al-Dīn 'Itr Madinah: al-Maktabah al-'Ilmiyah, 1972.

Ilzam. Hadis-hadis tentang Keimanan: Studi Kitab Qami' al-Thughyan Karya Imam Nawawi al-Bantany. Yogyakarta: UIN Sunan Kalijaga, 2014.

Ismail, Syuhudi. Kaidah Keșahịhan Sanad Hadis. Jakarta: Bulan Bintang, 1995.

Al-Lahidan, Dakhil ibn Shalih. Thuruq al-Takhrīj bi Hasabi al-Rāwī al-A'la. Madinah: al-Jamiah al-Islamiyah, $1422 \mathrm{H}$.

Al-Naysaburī, Muslim ibn Hajjaj. Șahịḥ Muslim. Tahqiq: Muhammad Fuad Abd al-Baqy. Bayrūt: Dar-Ihya al-Turats al-'Araby, tt.

Padil, Mo. Ideologi Tarbiyah Ulul Albab. Malang: UIN Maliki Press, 2008. Qadir, Zuli. Radikalisme Agama di Indonesia. Yogyakarta: Pustaka Pelajar, 2014.

Al-Qattan, Manna'. Mabāhith fì 'Ulūm al-Hadith. Kairo: Maktabah Wahbah, 1992.

Ridha, Muhammad Rashid. Tafsir al-Manār. Bayrūt: Dār al-Fikr, 1975.

Selly, Rosy. Kebangkitan Khilāfah Islamiyah Dalam Perspektif Pemikiran Hizbut Tahrir. Jakarta: UIN Syarif Hidayatullah, 2008.

Al-Thahhan, Mahmud. Taysīr Mustalāh al-Hadith. Iskandariyah: Markaz alHuda, $1415 \mathrm{H}$. 